\title{
Should The U.S. Seriously Contemplate Initiating A Value-Added Tax? What Are Other Countries Doing With This Type Of Tax?
}

Jack R. Fay, (Email: jfay@pittstate.edu), Pittsburg State University Judson P. Stryker, (Email: jstryker@stetson.edu), Stetson University

\begin{abstract}
The U. S. Tax System needs extensive changes. As Congress addresses these modifications, should it consider a value-added system? To what extent are other countries using the valueadded tax?
\end{abstract}

\section{INTRODUCTION}

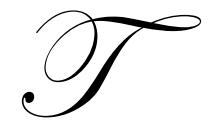

he current federal administration and a few Congressional leaders during the past couple of years have occasionally mentioned the possibility of considering a value-added tax (VAT) for the United States. Even though the details of such a tax system have been rather sketchy (at least publicly), there would be a possibility of a VAT tax being established as a replacement of the federal income tax or as an addition to the income tax. People should be reminded that in many countries the VAT tax became an addition to the income tax (even in cases where the governments had indicated that the tax would replace the income tax). Regardless of whether a VAT tax would be a replacement or an addition, such a new tax would be a major change in the U.S. overall tax system.

It behooves anyone who might be connected to making a proposal for a VAT for this country to conduct some serious investigations as to the advantages and disadvantages of a new tax system and to examine the current status of value-added taxes in other countries. It could be very beneficial to find some similarities and dissimilarities in VAT tax rates and rules in these nations in order to build some type of foundation for appropriate tax rates and rules in the U.S. if such a tax is seriously contemplated.

Also, as more and more U.S. universities (and universities throughout the world) have been adding international business, international accounting, and international taxation courses to their curricula, it is essential that some information relating to a variety of taxes be provided in some of these courses. It is also imperative that such information be as current as feasible.

\section{ARGUMENTS FOR AND AGAINST A CONSUMPTION TAX}

A consumption tax could be either a national sales tax or a European-style value-added tax. This article will focus on the VAT tax but some mention will be made in relation to a national sales tax.

President George W. Bush appointed an Advisory Panel on Federal Tax Reform, which began its deliberations in February, 2005. This panel heard testimony and statements from more than 100 witnesses. These individuals discussed the merits and disadvantages of a value-added tax, a consumed-income tax, a national retail sales tax, a flat income tax, a reform of the existing income tax, and other alternatives. The group filed their final report to the President in November, 2005. Their conclusions in this report and their recommendations, which are 
strictly advisorial suggestions, included some significant changes in our current income tax laws. They recommended against having a national sales tax, value-added tax, or any other alternative tax. The panel's vice chairman, former U.S. Senator John Breaux of Louisiana, said that a hybrid between an income tax and a consumption tax may have merit and should be studied carefully. Federal Reserve Chairman Alan Greenspan told the advisory panel that some type of consumption tax could spur greater economic growth, but he warned that the federal government could face significant problems making the transition to that type of a tax system. He also stated that one of the biggest advantages of a consumption tax, the potential of economic growth, could be greatly lost or reduced if the income tax system is poorly redesigned.

State Treasurer John Kennedy of Louisiana reminded the advisory panel that many states rely on sales tax for a significant portion of their tax revenue and that adding a federal sales tax would have a consequential impact on businesses and consumers. Bob Greenstein, founder and executive director of the Center on Budget and Policy Priorities, and William Beach, director of the data analysis center at The Heritage Foundation, both told the presidential panel that a consumption tax would be the worst of all worlds.

The panel's charge was to recommend ways to make federal taxes simpler and fairer. Simplicity and fairness, of course, are difficult to define and difficult to obtain. Former Senator Breaux states that our tax system has assumed that taxes should be levied according to a person's ability to pay and on fairness. However, he noted that there is no consensus of opinion among taxpayers, tax experts, and politicians on the definition of fairness. Attempting to create fairness has, in fact, often caused more complexity. A good example of this is the earned income tax credit (EITC), in which Congress had a goal of helping low-income people. Unfortunately, the related tax provisions are very complicated; the advisory panel was told that 72 percent of EITC recipients pay a tax preparer to do their tax returns. There are also tax laws that have been established for education, health care, charitable contributions, and retirement savings with the intent to reach fairness, but these rules are additionally complex.

Profess Michael J. Graetz of the Yale Law School proposed in July, 2005 to the advisory panel that a broadbased VAT be established and the income tax be eliminated for most taxpayers. He stated that the amount of VAT should be separately shown wherever goods and services are sold so that customers are aware of the tax amount. He suggested that businesses with less than $\$ 100,000$ in annual gross receipts (about 20 million of the 25 million small businesses in the U.S.) would be exempt from collecting VAT or filing returns. Graetz also recommended that the regular income tax be repealed but the alternative minimum tax (AMT) be continued with a higher exemption amount and the tax rate be decreased to a flat $25 \%$. The primary advantages of the proposals, according to Graetz, would be that these taxes would be easily enforceable, economic distortions would be minimized, and the compliance costs would be $25 \%$ to $33 \%$ of the present system's costs.

Thomas A. Wright, executive director of Americans for Fair Taxation, advocated a national retail sales tax. His recommendation was to administer the tax through existing state sales tax operations and allowing retailers to keep one quarter of one percent (.0025) of the taxes collected. He contended that a national sales tax is progressive since it taxes consumption and is the best measure of one's ability to pay. He also believed that this tax would encourage compliance via simplicity and transparency. David R. Burton, a partner of the Argus Group and senior fellow at the Free Enterprise Fund, recommended a business transfer tax (a consumption tax) in addition to a national sales tax. The business transfer tax would tax gross receipts from the sales of goods and services less the costs of purchasing goods and services from other businesses. Gross receipts from export sales would be exempt from the tax and certain adjustments would be levied on imports. This hybrid tax (national sales tax and business transfer tax), according to Wright, would meet the test of simplicity but would not totally meet the transparency test. Wright stated that Alexander Hamilton said two hundred years ago, "if a tax system is going to be transparent, then it should only tax consumers. Then the consumers know exactly how much government costs them. If they are happy with the services they get, they will gladly pay the toll." 


\section{WHAT OTHER COUNTRIES ARE DOING WITH VAT}

As indicated earlier, this article will be centered on the value-added tax and not on any other type of consumption tax. Again the primary purpose of this research study and paper is to provide some current information on tax rates and rules in relation to the VAT tax in countries throughout the world.

To make some comparisons on a regional basis, the authors elected to categorize the world into four sections: (1) Americas, (2) Asia/Pacific Basin, (3) Europe, and (4) Africa/Middle and Near East.

The following tables are brief descriptions of VAT tax rates and rules for 114 countries.

\section{$\underline{\text { COUNTRY }} \underline{\text { VAT Tax Rates and Rules }}$}

\section{Americas:}

Antigua and Barbuba

Argentina

Bahamas

Barbados

Bermuda

Bolivia

Brazil

Canada

Cayman Islands

Chile

Colombia
There is no VAT.

General rate of $21 \%$. The rate is applied on the sales value of products and services (with a few exceptions). The tax is levied on imports but not on exports.

There is no VAT.

Standard rate of $15 \%$, which is applicable to a wide range of goods and services; $7.5 \%$ rate on hotel services. Some products are exempt, such as exports, certain supplies, food, some medicines, and crude oil. Some services are exempt, such as financial services, sale of real estate, public

transportation, medical services, and education.

There is No VAT.

13\% VAT rate; certain imports are exempt from the tax.

Normally $10 \%$ to $15 \%$, but may range up to over $300 \%$. The tax is levied on imports, sales, and transfers of goods and products (in the form of a federal excise tax), and there is a state sales and service tax ranging from $7 \%$ to $25 \%$.

7\%. It is a federal goods and services tax (GST) and is applied at each level in the manufacturing and marketing chain for most goods and services. The tax does not apply to exports, groceries, and certain supplies.

There is no VAT.

$18 \%$. VAT is applicable on transfers of products and services; it is also Taxable on imports.

$16 \%$ on the value of goods and services, including imports, unless specifically exempt. Sales and imports of certain motor vehicles are subject to a rate of $38 \%$; others are subject to $21 \%$ or $23 \%$. A $2 \%$ rate (as of 2005) is levied on exports of services. 
Costa Rica

Dominican Republic

Ecuador

Guatemala

Guyana

Jamaica

Mexico

Netherlands Antilles

Panama

Paraguay

Peru
$10 \%$ to $75 \%$. The VAT is called selective consumption tax, and it is only on "nonessential" goods. The tax is levied at only one stage in the sale of merchandise.

$12 \%$ on industrialized goods, imports, and services ( $6 \%$ on advertisement services); no tax on exports. Some living essentials and certain services are exempt. There is also a selective consumption tax, ranging from $19.5 \%$ to $78 \%$, on domestic manufactures (alcohol products and cigars), certain imported goods, and certain types of services (such as insurance, international air transportation, long distance telephone calls, and hotel rooms).

$12 \%$ on the transfer of goods, imports of goods and imports of services. Certain goods and services are exempt from the tax. Certain companies are required to withhold $30 \%$ of the VAT applicable on their purchases of goods and $70 \%$ on their applicable purchases of services. Some taxpayers and companies are required to withhold $100 \%$ of the VAT on payments made to individuals. There is also a special consumption tax on automobiles, airplanes, helicopters, boats, cigarettes, alcoholic beverages, soft drinks, and telecommunication services.

$12 \%$ on the sale or transfer of goods, chattels, real estate, non-personal services, rentals of goods and chattels, and imports. Some goods and services are exempt from the tax. The VAT charged to customers is set off against VAT paid to suppliers with the net amount paid to the tax authorities on a monthly basis.

No VAT. There is a consumption tax on certain goods, certain imports, and certain exports.

$15 \%$ - standard rate. There are higher rates on some goods, such as tobacco products, liquor, motor vehicles, and fuels. Some items, such as groceries and household goods, are exempt from the tax. The value-added tax is called the General Consumption Tax (GCT).

$15 \%$ - general rate. The tax is levied on sales of goods and services, lease payments, and imports. The tax is $10 \%$ on goods and services in the border zones. Sales of most food products and the sales of medicines are exempt. There are many types of transactions that are exempt from VAT; these include sales of land, credit instruments, residential construction, medical services, education, salaries and wages, sales of publications, most exports, sales of agricultural goods and services, and sales and rentals of farm machinery and equipment.

There is no VAT.

5\%. The VAT is levied on many consumer goods (not foods and medicines) and most services (not health care, transportation, education, exports). The VAT rate is $10 \%$ on alcohol and $15 \%$ on cigarettes.

9.09\%. The tax is payable by all corporations and by individuals or associations of individuals providing personal services.

$19 \%$ - general rate. The tax is applicable to the sale of goods within Peru, providing or using of services in Peru, construction contracts, first sales of real estate made by contractors, and imports of goods. This VAT is determined on a monthly basis; it is calculated by taking the gross tax and then deducting the VAT paid upon the applicable goods and services (fiscal credit). 
Puerto Rico

(U.S. Possession)

St. Lucia

Trinidad and Tobago

United States

Uruguay

Venezuela

\section{Asia/Pacific Basin:}

Australia

Azerbaijan

Cambodia

China

Fiji

Hong Kong

India

Indonesia
There is no VAT.

There is no VAT.

$15 \%$. The tax is applicable to a wide range of goods and services. Many items are exempt from the tax, such as unprocessed foods, agricultural supplies, crude oil and natural gas, exports, real estate brokerage, residential rentals, educational services, and yachting services to nonresidents.

There is no VAT.

$23 \%$ - basic rate. A few items are taxed at $14 \%$ or are tax exempt.

$16 \%$ - general rate. The rate may change every year, ranging from $8 \%$ to $16.5 \%$. The tax is paid by the final consumer for all types of products and services although there is a long list of exempt products and services. Each business entity involved in the process from the sale of raw materials to the production and distribution of finished products to the final consumer is required to bill its customers the tax (output tax) and to pay the tax on its purchases or imports of goods and services (input tax), crediting the amounts paid against the amounts due; this is the net amount payable by each entity, which represents a tax on the value added.

10\%. The value - added is called goods and services tax (GST). The federal government levies the tax but distributes the revenues to the state governments. The tax is applied at each level in the manufacturing and marketing chain and applies to most goods and services. Exempt from the tax include some food products, exports, life insurance, residential rentals, and most health, medical and educational supplies.

There is no VAT.

10\%. The tax is levied on the price of most goods and services. Generally, the list of exemptions include: most exports, servicesrendered outside of Cambodia, public postal service, medical and dental services, electricity, public transportation, insurance services, and primary financial services.

17\%. China has a turnover tax system, which includes a VAT, business tax, and consumption/excise tax. There is a reduced rate of $13 \%$ (or tax exempt) on the sale of certain necessity goods and imports of certain special equipment; also exports of all foreign investment enterprises are tax exempt.

12.5\%. Exempt from VAT are financial services, residential rentals, Educational services, exports, and international transportation.

No VAT and no other broad-based consumption tax.

No VAT. There is an excise tax on most of goods man ufactured and a service tax on certain types of services.

$10 \%$. The VAT law permits amendments within a range of 5\% to $15 \%$. Exports of goods are exempt from the tax. 
Japan

Kazakhstan

Korea, Republic of

Macau

Malaysia

Malta

New Zealand

Pakistan

Philippines

Russian Federation

Singapore

Solomon Islands

Sri Lanka

Tahiti
5\%. The VAT (consumption tax) is levied on goods and services. Exports and certain services provided to nonresidents are exempt from the tax.

$15 \%$. The tax is levied on most products and services. Exports of goods are exempt.

10\%. Sales and transfers of most goods and services are subject to the tax. Exports are exempt.

No VAT. There is a consumer tax (excise duty) on certain imports of goods.

$5 \%$ to $25 \%$. The ad valorem (sales tax) tax is applicable to most imports of goods and goods manufactured in the country.

$18 \%$ - standard rate. The VAT rate for hotel accommodations, alternative energy equipment, and electricity is 5\%. Exempt are exports, food, and certain other goods and services. New Caledonia No VAT. There is a tax of $4 \%$ on certain services.

$12.5 \%$ - standard rate. The value added tax is a goods and services tax (GST), and it is applicable to most goods and services. Exports and financial services are exempt from the tax.

15\%. The value-added tax is called a sales tax, and it is generally levied on the value of goods.

$10 \%$. The VAT is applicable to almost all sales of services, imports, and sales, barter exchange or rentals of goods or tangible and intangible properties. Certain exports and services are exempt from the tax.

18\%-standard rate. A $10 \%$ rate applies to certain food products, children's clothing, prescription drugs and medical goods. The $18 \%$ or $10 \%$ rate applies to imports of goods; exports and related services are exempt. The VAT is applicable to the value added by each element in the chain of production from of production from producer to consumer.

5\%. The value-added tax is called goods and services tax (GST). Most goods and services are taxable, with the exceptions of financial services, life insurance, and the sale or rental of residential properties.

$10 \%$. The VAT is primarily applicable to most services, which include telephone services, restaurant services, videos and video rentals, cinema tickets, professional services, computer services, electronicrepairs and maintenance, hairdressing services, and laundry services.

15\%. The tax is levied on goods and services (including financial services). Exempt from the tax are exports of goods, services related tointernational transport of goods and passengers, and certain services consumed outside of the country.

$10 \%$ - standard rate on services, $16 \%$ - intermediate rate on most products, and $6 \%$ - lower rate on most food products, books, and certain other items. There are exemptions for financial services, insurance, property transactions, education and health services, water distribution, and oil products. Imports of goods are taxable, but exports of goods are tax exempt. 
Taiwan

Thailand

Turkey

Ukraine

Uzbekistan

Vietnam

\section{Europe:}

Austria

Belgium

Bulgaria

Channel Islands, Guerney No VAT.

Channel Island, Jersey exempt.
$5 \%$ - standard rate. The rate is $2 \%$ for banks, insurance companies, trusts, security and futures firms, and pawnshops. Re-insurance operators pay $1 \%$.

10\%. Exports are exempt. Certain goods and services are exempt, which include basic food, education, health care, interest, leasing ofimmovable property, and real estate sales.

$18 \%$ - standard rate. Telecommunication services and fuels are taxed at $18 \%$. Basic food and books are taxed at $8 \%$. Certain agricultural products, newspapers, magazines, and most goods subject to financial leasing have a $1 \%$ VAT rate.

20\%. The tax is levied on domestic sales and imports of goods, works, and services; certain exports are subject to the $20 \%$ tax and others are exempt. Many goods and services (such as educational services, health care services, pharmaceuticals, and charitable activities) are exempt from the VAT.

20\%. The value-added tax is a sales tax. The tax is applicable to taxable turnover and taxable imports. Exports are generally exemptfrom the tax as well as insurance and most types of financial services. VAT is generally paid once each month.

$10 \%$ - standard rate. The tax is levied on domestic goods and services. Some items are taxed at 5\%. There is a wide range of exemptions. Exports of goods and services are tax

$20 \%$ - standard rate. The tax is levied on most goods and services. A few goods and services are taxed at $10 \%$. Exports are tax exempt.

$21 \%$ - standard rate. The VAT is applicable on domestic goods and services and on imports. Certain goods are taxed at $12 \%$ or $6 \%$. Some goods and services are tax exempt; some examples are most banking and financial services, insurance, most sales of real estate, rentals of immovable property, medical services, legal services, and culturalservices.

20\%. Exports and most services are exempt from the tax. The tax base includes the price of the goods, customs and excise duties (if any), and certain other expenses (such as commissions, packing, transport, andinsurance costs).
Croatia

Cyprus

Czech Republic

Cyprus

$22 \%$ The VAT is a consumption tax that is borne by the final consumer of domestic goods and services. An annual VAT return must besubmitted by April 20 of the following year. VAT is also applicable to the sale of new buildings. A few types of goods are tax exempt.

$15 \%$ - standard rate. Tax exemptions include exports, food, medicines, rents, insurance, financial services, education, health, and welfare. Most international business entities are exempt from the tax, butrecently some have become subject to the VAT.

$22 \%$ - standard rate. The tax is levied on domestic goods and most services. Some goods and services are taxed at 5\%. Exempt from the VAT include real estate rentals, exports, financial and insurance services, radio and TV broadcasting, education, health, and welfare. 
Denmark

Faroe Islands

Finland

France

Germany

Greece

Hungary

Ireland

Isle of Man

Italy

Latvia

Liechtenstein
$25 \%$ - general rate. The tax is charged as a percentage times the sales price.

25\%. The tax is charged as a percentage times the sales price.

$22 \%$ - standard rate. Food and animal feed are taxed at 17\%. Medicines, books, cinema, sports activities, passenger transport, and hotel accommodations are taxed at $8 \%$. Financial services, healthcare services, newspaper subscriptions, and periodicals are tax exempt.

$19.6 \%$ - normal rate. The value-added tax is called a turnover tax. Specific sales of goods and services are taxed at $5.5 \%$ or $2.1 \%$. Exports and certain services are tax exempt.

$16 \%$ - standard rate. The tax is levied on domestic sales and services. The VAT is $7 \%$ on certain transactions.

$18 \%$ - standard rate. Basic necessities are subject to an $8 \%$ rate; books, newspapers, and periodicals are subject to a $4 \%$ rate. Exports of goods and certain services to individuals, and supplies of goods and services to legal entities are generally tax exempt.

$25 \%$ - general rate. $15 \%$ is the rate charged for food, essential goods, and certain services; $5 \%$ is the applicable rate for some medicines. Exempt from the VAT include exports, most land transactions, residential property leases, medical services, cultural and sporting activities, educational services, financial services, and insurance.

$21 \%$ - standard rate. The VAT rate is $13.5 \%$ for various goods and services, including electricity, fuels (except motor fuels), developed property, newspapers, certain building materials, hotel accommodations, certain tourist-related services, restaurants, cinema and cultural activities, certain agricultural services, waste disposal, repairs and maintenance of movable goods, and photographic and similar services. The VAT rate is $4.4 \%$ for livestock (including horses) and greyhounds. Exempt from the VAT include exports of goods, fertilizers, books, food, medicines, children clothing and footwear, certain financial services, insurance, transport of passengers, funeral undertaking, medical services, and most educational services.

$17.5 \%$ - standard rate. The VAT is levied on most goods and services. Domestic fuel and power and certain other supplies are charged at a 5\% rate. Most exports, most food, most public transport, books and publications, and certain other essential goods and services have a zero-rated VAT. Also certain land interests, financial services, insurance, education, health, and welfare services are tax exempt.

$20 \%$ - standard rate. The tax is levied on most goods and services. Mass consumption goods and utilities may be taxed at $20 \%$ or at $10 \%$. Food products may be taxed at $10 \%$ or at $4 \%$. Export sales are tax exempt.

$18 \%$ - standard rate. Most goods and services are subject to VAT. Medicines, medical equipment, scientific literature, and school literature are charged a 5\% rate. Also books, mass media, hotel accommodations, water services, and sewerage services are taxed at $5 \%$. Certain services supplied by nonresidents to Latvian companies are levied an $18 \%$ tax rate. Exports of goods and services are tax exempt.

$7.6 \%$ - standard rate. The VAT is applied to domestic goods and services and imports of services. Lodging is taxed at $3.6 \%$ rate; certain goods (e.g., foods, books, and pharmaceuticals) are taxed at a rate of $2.4 \%$. Exempt from VAT include most exports, healthcare, education, culture, and most banking services. 
Lithuania

Luxembourg

Malta

Norway

Poland

Portugal

Romania

Slovak Republic

Slovenia
18\%. The VAT is applicable on imports of goods and domestic goods and services. There are many tax-exempt goods and services. Most exports of goods and services are exempt. Domestic goods and services that are exempt include medical goods and services, social services, education, certain postal services, turnover of securities and raffles, funeral goods and services, publishing, residential rentals, and land rentals.

$15 \%$ - standard rate. The VAT is applicable to the proceeds of domestic sales and services. The rate is $12 \%, 6 \%$, or $3 \%$ on certain transactions. The taxpayers may offset against their VAT payable the amount of such tax charged to them by their suppliers or assessed on imports. Generally, banking, insurance, reinsurance, and holding operations are tax exempt.

$18 \%$ - standard rate. Hotel and holiday accommodations, alternative energy equipment, and electricity are levied a 5\% rate. Exempt with credit are exports, food and certain other goods and services. Netherlands $19 \%$ - standard rate. The tax is applicable to domestic goods and services and imports of goods. The rate is $6 \%$ on certain prime necessities. Tax exempt items include intra-European Union supplies, exports and imports stored in bonded warehouses; medical, social, cultural, and educational services; banking and financial transactions; insurance; and transactions in shares.

$24 \%$ - normal rate. The tax is based on sales of goods and services.

$22 \%$ - standard rate. The VAT is charged to the sales of goods and services. The VAT is $7 \%$ on certain items, including pharmaceutical products and passenger transport services. Tax exempt items include financial, insurance, and educational services. Exports of goods outside the EU are zero-rated.

$19 \%$ - normal rate. Subject to a $12 \%$ rate include the following: basic canned goods, fruit jellies, fats, honey, coffee, natural water, fruit juices, decorative flowers, restaurant services, petroleum and diesel fuel for equipment for agricultural and fishing activities, and certain ecological equipment. Subject to 5\% VAT include the following: food, books, certain pharmaceutical products, milk products, and certain services. Exports and sales of goods that are intra-EU are zero rated.

$19 \%$ - standard rate. The VAT applies to most supplies of goods and services, including imports. A reduced rate of $9 \%$ applies to the following: admission fees to museums, historical monuments, zoos and botanical gardens, fairs and exhibitions; supply of school manuals, books, newspapers and periodicals; supply of prostheses and orthopedic products; medicines; and hotel accommodations. Exempt items with credit include: exports of goods, transport and related services, goods sold at duty-free shops, international transport of passengers, certain operations performed in free trade zones and free harbors, and supply of goods to bonded warehouses and related services. Exempt items without credit include: financial and banking, insurance, leases of real estate, and certain medical, veterinary, social assistance, and educational organizations.

$20 \%$ - standard rate. The VAT applies to domestic supply of goods and services. Certain goods and services are taxed at 14\%. Exports of goods and certain services are exempt with credit. Exempt without credit include financial activities, insurance, radio and TV broadcasting, education, healthcare, and social welfare.

No VAT. 
Spain $16 \%$ - ordinary rate. The VAT applies to domestic supplies of goods and services. The applicable rate is $7 \%$ for most basic necessities (food and agricultural products), hairdressing services, and works performedby bricklayers or personal homes. Certain items are taxed at $4 \%$ (e.g., bread, milk, books, and medicines). In the Canary Islands the IGIC tax is used rather than the VAT; this tax is similar to a VAT. The applicable rates are $2 \%, 5 \%, 9 \%$, or $13 \%$ ( $15 \%$ or $25 \%$ for tobacco). Certain items are tax exempt. In Ceuta and Melilla a sales tax is used Instead of a VAT.

Sweden $25 \%$. The VAT is levied on the sale of most goods and services. A few types of goods and services are subject to a reduced rate.

Switzerland

7.6\% - standard rate. The tax is levied on the proceeds of sales and services. Basic necessities are taxed at $2.4 \%$, and services related to accommodations are taxed at $3.6 \%$. Generally, the taxpayer may offset against the VAT payable the amount of such tax charged by suppliers or paid on imports.

United Kingdom $\quad 17.5 \%$ - standard rate. The VAT is levied on the supply of most goods and services. Domestic fuel and power and certain other supplies are subject to a 5\% rate. Most exports, most food products, most public transport, books and publications, and certain other essential goods are zero-rated while certain land interests, insurance, financial services, education, health, and welfare are tax exempt.

\section{Africa/Middle And Near East:}
Bahrain
No Vat.
Botswana
No Vat.
Brunei Darussalam
No Vat.
Congo
No VAT. Rather than a consumption tax, Congo has a national sales tax (ranging from $0.25 \%$ to $30 \%$ ) on most domestic goods and services, imports of services, and a few types of exports.
Egypt
No VAT.
Ghana
12.5\%. Most supplies of goods and services are subject to the VAT. Most professional services are subject to the $12.5 \%$ VAT; these include accounting services, financial and tax consulting, legal services, management services, surveying and architectural services, insurance, engineering and technical services, and cellular phone services. Exports are zero rated.
Iran
$3 \%$. The tax is levied on most sales of goods and services.
Israel
$17 \%$. The VAT is charged on most goods and services. Exports of goods and services and certain other transactions are zero rated while certain transactions are tax exempt. Banking and financial institutions pay the $17 \%$, based on their total payroll and on profits. Not-for- profit organizations pay a VAT of $8.5 \%$ of their total payroll.

Ivory Coast

$20 \%$. The VAT is a non-cumulative tax applicable to the sales of goods and services. The VAT may be recoverable under certain restrictions. 
Kenya

Mauritius

Mozambique

Namibia

Oman

Qatar

Saudi Arabia

South Africa

Swaziland

Tanzania

Uganda

United Arab Emirates

Zambia

Zimbabwe
$16 \%$ - standard rate. The VAT is levied on the manufacture and supply of certain goods, the provision of certain domestic supplies, and imports of certain goods and services. Restaurant food is taxed at $14 \%$. Food at the retail level, pharmaceuticals, exported coffee, and certain other products are tax exempt. Most exports of goods and services, supply of goods to the government, and the supply of goods or services to designated development projects have a zero rating.

15\%. Generally, all goods and services are taxed; certain supplies are tax exempt. The VAT replaced the sales tax in 1998.

$17 \%$ - standard rate. The VAT is applicable to the sale of most domestic and imported goods and services. Generally, the VAT is recoverable by corporations, except those in certain activities (such as financial and insurance operations, leasing, and sale of immovable property).

15\%. The VAT is applied whenever ownership of goods changes, services are provided, and goods are imported. Certain good and services are tax exempt. On imported goods there is a surcharge of $10 \%$, which means that the VAT is $16.5 \%$.

No VAT.

No VAT.

No VAT.

14\%. The VAT is applied to a wide variety of domestic and imported goods and services. Exports of goods and services are generally zero rated. Some supplies are tax exempt.

No VAT. There is a consumption tax (sales tax) of $14 \%$ on imported goods, on the first sale of manufactured domestic goods, and on most professional services; the tax is $25 \%$ on cigarettes and liquor.

No VAT.

17\%. The VAT is levied on most goods and services. Some supplies are zero rated; these include exports of goods and services, medicines, educational materials, international transportation of passengers or goods and related services, milk, and locally produced cereals. Tax exempt supplies and services include unprocessed food, agricultural products and livestock, agricultural and dairy machinery, financial and insurance services, medical goods and services, educational services, most passenger transportation services, petroleum fuels, computers(also printers and accessories) and computer software, mobile toilets, life jackets, insecticides, certain land and property transactions, and gambling services; imported services are charged with the VAT.

No VAT.

$17.5 \%$ - standard rate. The VAT is applicable to most goods and services. Certain goods and services are tax exempt. Exports of goods and services, medicines, farm produce, and uncooked meat and poultry are zero rated.

No VAT. There is a consumption tax (sales tax) on certain goods and services; the tax ranges from $5 \%$ to $25 \%$. 


\section{ANALYSES AND COMPARISONS}

This investigative study indicates that there is a significant diversity around the world concerning the valueadded tax (VAT) in relation to the tax rates and just what is or is not taxed. There is no question that the VAT is very popular (at least for the government's sake) throughout the world as 87 nations, out of the 114 that were investigated in this study, make use of the VAT in order to obtain federal revenues. Most of these countries use the VAT rather extensively as they levy the tax on most goods and services even though certain goods and services may be exempt or zero rated. It is rather obvious that the VAT has not been established to replace the income tax system, considering the fact that all 87 countries with a VAT also have a corporate income tax and 83 of the countries continue to have an individual income tax. Many people in the United States who in recent years have proposed the idea of setting up a VAT system in this country tend to imply or state that it would replace the federal

Individual income tax system (and possibly the corporate income tax); but these authors have a strong feeling that if a VAT system were initiated here, it is more likely that it would become an additional tax rather that be used to replace the income tax as it is currently done in 87 (or 83) other countries.

Comparisons of the VAT systems and rules for 114 countries can not be easily illustrated in practical formats nor can much detailed information for each country be provided in a general taxation article, but the following data does show some comparative facts or particulars related to the area of the VAT.

The following table shows the number of countries in each regional section that do not utilize the VAT, the number that do have the VAT, and the number of countries with the VAT that also have a corporate income tax and an individual income tax.

$\begin{array}{lcccc} & \text { No VAT } & \underline{\underline{\text { VAT }}} & \begin{array}{c}\text { Corporate } \\ \text { Income Tax }\end{array} & \begin{array}{c}\text { Individual } \\ \text { Income Tax }\end{array} \\ \begin{array}{lcccc}\text { Americas } \\ \text { Asia/Pacific Basin }\end{array} & 5 & 19 & 19 & 17 \\ \text { Europe } & 3 & 25 & 25 & 31 \\ \begin{array}{l}\text { Africa/Middle and } \\ \quad \text { Near East }\end{array} & \underline{-11} & \underline{12} & \underline{12} & \underline{12} \\ \text { Totals } & \mathbf{2 7} & \mathbf{8 7} & \mathbf{8 7} & \mathbf{8 3}\end{array}$

The next table illustrates (by regional section) what the standard VAT rate is in those countries that have a VAT (or a consumption tax that is similar to a VAT) and whether the VAT is levied primarily on imports, exports, imports and exports, or only on domestic goods and services. Many of the countries that have a standard rate also have lower rates for certain goods and/or services. In addition to possible special rates for certain items, many countries exempt or zero rate imports, exports, certain imports or exports, or certain domestic goods and/or services. 


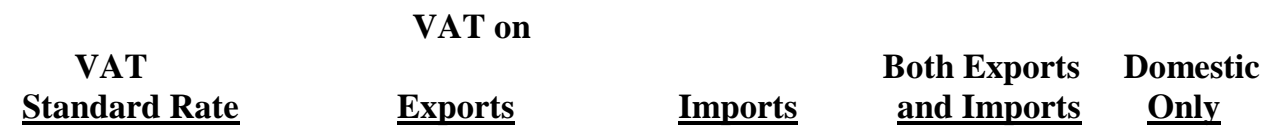

Americas

$$
\begin{array}{cr}
20-23 \% & -2 \\
15-19 \% & -9 \\
10-14 \% & -5 \\
5-9.09 \%-3
\end{array}
$$

Asia/Pacific Basin

$$
\begin{gathered}
20 \%-1 \\
15-19 \%-10
\end{gathered}
$$$$
10-14 \%-12
$$$$
5 \%-2
$$

Europe

$$
\begin{gathered}
20-25 \%-15 \\
15-19.6 \%-14 \\
7.6 \%-2
\end{gathered}
$$

Africa/Middle and

Near East

$$
\begin{aligned}
20 \% & -1 \\
15-19 \% & -8 \\
10-14 \% & -2 \\
3 \% & -1
\end{aligned}
$$

1

6

7

\begin{tabular}{|c|c|c|c|c|}
\hline $\begin{array}{c}\text { VAT } \\
\text { Standard Rate }\end{array}$ & $\begin{array}{r}\text { VAT on } \\
\text { Exports }\end{array}$ & Imports & $\begin{array}{l}\text { Both Exports } \\
\text { and Imports }\end{array}$ & $\begin{array}{c}\text { Domestic } \\
\text { Only }\end{array}$ \\
\hline $\begin{array}{l}20-25 \%-19 \\
15-19.6 \%-41\end{array}$ & & & & \\
\hline $\begin{array}{c}10-14 \%-19 \\
3-9.09 \%-\end{array}$ & 1 & 55 & 17 & 14 \\
\hline
\end{tabular}

5
0

19

22

8

0

0
$3 \quad 3$

2

2

The final table indicates the worldwide totals for the 87 countries that have a VAT tax, showing the standard rates and on what the tax is primarily levied.

\section{CONCLUSIONS}

As mentioned previously, useful tabular formats showing data relating to value-added taxes are difficult to make. However, as stated in the introductory section of this manuscript, the value-added tax has been a rather significant recent topic as a possible tax substitution or addition in the United States. Even though at the present time it does not appear likely to be adopted in the U.S. anytime in the near future, there is always a possibility that during the next three years the current administration could make a proposal to Congress to pass such a tax (especially if more emergencies and demand for more revenues should arise). It would become obligatory for members of the U.S. Senate and House of Representatives to investigate and study all the ramifications that would be related to the institution of a new major and complex tax system. One place to initiate such an investigation would be to look at a preview of the current status of value-added taxes in other countries, which is provided by the authors in this paper. The next step might be to survey the tax authorities in those countries to try to determine how successful these taxes have been in relation to the desired revenues and the collection processes, any pitfalls in the tax systems, and whether or not any changes are contemplated in the future. 


\section{REFERENCES}

1. $\quad$ Corporate Taxes 2004-2005 Worldwide Summaries. PricewaterhouseCoopers.

2. Mary Dalrymple, Experts Warn Against Consumption Tax, SmartPros Newsletter, pp.1-2. March 31, 2005.

3. Mary Dalrymple, Presidential Panel Hears About Tax System, SmartPros Newsletter, pp. 1-3. May 17, 2005.

4. Jack R. Fay, World-Wide Comparisons of Corporate Income Taxes, Oil, Gas, \& Energy Quarterly, pp. 683703. February, 2001.

5. Jack R. Fay, A State-of-the-Art Potpourri Report of Business Taxes (Other Than Income Taxes) in over 100 Countries from A to Z (Antigua to Zimbabwe), Oil \& Gas Tax Quarterly, pp. 427-449. March, 1994.

6. Roger Russell, Bush's tax overhaul panel hears alternative proposals, Accounting Today, pp. 10-11. June 20July 10, 2005.

$\underline{\text { Notes }}$ 